\title{
Inovasi Kebijakan Pemerintah Daerah dalam Penanganan Covid-19 di Indonesia
}

\author{
Dian Kus Pratiwi \\ Universitas Islam Indonesia, Yogyakarta, Indonesia \\ *email: dian.pratiwi@uii.ac.id
}

DOI: https://doi.org/10.37729/amnesti.v3i1.929

Submitted: November 2020

Revised: Januari 2021

Accepted: Januari 2021

\begin{tabular}{|c|c|}
\hline & ABSTRAK \\
\hline $\begin{array}{l}\text { Kata Kunci: } \\
\text { Inovasi } \\
\text { Kebijakan, } \\
\text { Penanganan } \\
\text { Covid-19, } \\
\text { Otonomi Daerah }\end{array}$ & $\begin{array}{l}\text { Kondisi darurat akibat Covid-19 dalam kerangka negara kesatuan } \\
\text { tidak hanya menjadi tanggung jawab pemerintah pusat, namun } \\
\text { perlu peran dan tanggungjawab pemerintah daerah. Hal inilah } \\
\text { penting bagi pemerintah untuk melakukan inovasi kebijakan } \\
\text { penanganan pandemi Covid-19 tanpa mengesampingkan kebijakan } \\
\text { yang telah di keluarkan oleh pemerintah pusat. Penelitian ini } \\
\text { bertujuan untuk mengidentifikasi urgensi dan bentuk inovasi } \\
\text { kebijakan pemerintah daerah dalam penanganan pandemi Covid-19. } \\
\text { Penelitian dilakukan secara yuridis normatif dengan pendekatan } \\
\text { kualitatif terhadap urgensi inovasi kebijakan pemerintah daerah dan } \\
\text { bentuk inovasi kebijakan pemerintah daerah dalam penanganan } \\
\text { Covid-19. Hasil penelitian menunjukan bahwa inovasi kebijakan } \\
\text { pemerintah daerah dalam penangangan Covid-19 di Indonesia } \\
\text { penting dilakukan dengan alasan: } 1 \text { ) dalam konteks negara kesatuan } \\
\text { terdapat hubungan antara pemerintah pusat dan daerah; } 2 \text { ) adanya } \\
\text { problematika hubungan antara pemerintah pusat dan pemerintah } \\
\text { daerah secara umum maupun dalam penanganan Covid-19 di } \\
\text { Indonesia mengakibatkan ketidak efektifan kebijakan penanganan } \\
\text { Covid-19; 3) sejumlah peraturan dan kebijakan pemerintah pusat } \\
\text { belum cukup efektif mengatasi pandemi Covid-19; 4) pemerintah } \\
\text { daerah memiliki tanggung jawab langsung kepada masyarakat di } \\
\text { daerah; 5) bahwa inovasi kebijakan merupakan bagian dari } \\
\text { kepentingan nasional guna melaksanakan tujuan bernegara yang } \\
\text { berpegang pada asas solus populi suprema lex. Bentuk inovasi } \\
\text { kebijakan yang dilakukan pemerintah daerah dalam penanganan }\end{array}$ \\
\hline
\end{tabular}


pandemi Covid-19 diantaranya: 1) inovasi kebijakan terkait pemulihan sektor birokrasi dan pelayanan masyarakat; 2) berkaitan dengan sektor kesehatan dan ketertiban masyarakat; dan 3) inovasi dibidang ekonomi dengan memberikan fasilitas perpajakan.

$\begin{array}{ll}\text { Keywords: } & \text { ABSTRACT } \\ \text { Policy } & \text { The emergency conditions due to Covid-19 within the framework of a } \\ \text { Innovation, } & \text { unitary state are the central government's responsibility and the roles and } \\ \text { Handling Covid- } & \text { responsibilities of local governments. The government needs to innovate } \\ \text { 19, Regional } & \text { government's policies. This study aims to identify the urgency and forms of } \\ \text { Autonomy } & \text { innovation in local government policies in handling the Covid-19 pandemic. } \\ & \text { The research was conducted in a normative juridical manner with a } \\ \text { qualitative approach to the urgency of local government policy innovation } \\ \text { and forms of local government policy innovation in handling Covid-19. The } \\ \text { results of the study show that innovation in local government policies in } \\ \text { handling Covid-19 in Indonesia is important for the following reasons: 1) in } \\ \text { the context of a unitary state, there is a relationship between the central and } \\ \text { regional governments; 2) the existence of problematic relations between the } \\ \text { central government and regional governments in general as well as in } \\ \text { handling Covid-19 in Indonesia, resulting in the ineffectiveness of policies } \\ \text { for handling Covid-19; 3) several central government regulations and } \\ \text { policies have not been effective enough to overcome the Covid-19 pandemic; } \\ \text { 4) local governments have direct responsibilities to local communities; 5) } \\ \text { that policy innovation is part of the national interest in order to carry out } \\ \text { the goals of the state adhering to the solus populi suprema lex principle. The } \\ \text { forms of policy innovations carried out by local governments in handling the } \\ \text { Covid-19 pandemic include 1) policy innovations related to the recovery of } \\ \text { the bureaucratic sector and public services; 2) related to the health sector } \\ \text { and public order; and 3) innovation in the economic field by providing tax } \\ \text { facilities. }\end{array}$

\section{PENDAHULUAN}

Perkembangan Wabah Corona Virus Disease 2019 (Covid 19) telah ditetapkan sebagai pandemi oleh World Health Organization (WHO). Hal ini mengingat penyebaran Corona Virus Disease 2019 (Covid 19) tidak hanya menjangkit daratan Cina khususnya Wuhan, namun juga di berbagai negara dunia. Hal ini lah yang mengakibatkan saat ini negara-negara mengupayakan segala daya upaya agar dapat memutus rantai penyebaran virus corona, dan menekanangka penyebaran dan bertambahnya korban (Iswahyudi et al., 2020).

Untuk mengatasi covid-19 ini, diperlukan cara-cara yang tidak biasa. Terlebih, sistem norma hukum diberlakukan berdasarkan undang-undang dasar dan perangkat peraturan perundang-undangan yang secara resmi 
diadakan untuk mengatur berbagai aspek yang berkenaan dengan penyelenggaraan kegiatan bernegara pada umumnya dalam keadaan normal, namun pada keadaan tertentu juga memungkinkan adanya keadaan lain yang bersiat tidak normal, dimana sistem hukum yang biasa itu tidak dapat diharapkan efektif untuk mewujudkan tujuan hukum itu sendiri (Sagama, 2016).

Dalam konteks Negara Indonesia, instrumen hukum perihal "keadaan bahaya" dan "hal ihwal kegentingan yang memaksa" dapat ditemukan landasan hukumnya dalam Pasal 12 dan Pasal 22 Undang-Undang Dasar Negara Republik Indonesia Tahun 1945 (UUD NRI 1945). Pasal 12 menegaskan bahwa "Presiden menyatakan keadaan bahaya, syarat-syarat dan akibatnya keadaan bahaya ditetapkan dengan undang-undang". Perundang-udangan yang merupakan penjabaran ketentuan Pasal 12 yang masih berlaku sampai sekarang adalah Perppu Nomor 23 Tahun 1959 tentang Keadaan Bahaya. Di dalam Perppu tersebut, diatur berbagai hak berkenaan dengan pemberlakuan dan pengakhiran serta tentang syarat-syarat dan akibat hukum pemberlakuan keadaan bahaya. Meskipun secara umum keadaan bahaya dibedakan antara keadaan darurat (staat van beleg) dan keadaan perang (staat van oorlog), dalam UU yang terakhir ini, keadaan bahaya itu dibedakan menurut tingkatannya antara keadaan darurat perang; keadaan darurat militer; dan keadaan darurat sipil (Nuh, 2011). Perkataan keadaan darurat dianggap identik atau merupakan sinonim dari perkataan keadaan bahaya Kondisi darurat sipil, seperti timbulnya ketegangan sosial, bencana alam, atau yang sejenisnya dapat dimasukkan ke dalam kategori "state of tension" atau kondisi tegang (Adhari, 2019).

Kondisi kedaruratan akibat Covid ini pemerintah telah menetapkan virus corona (Covid 19) sebagai bencana nasional melalui Keputusan Presiden Nomor 12 Tahun 2020 tentang Penetapan Bencana Non-alam Penyebaran Covid-19 sebagai Bencana Nasional (Samudro \& Madjid, 2020). Sebelumnya Presiden juga telah mengeluarkan sejumlah peraturan dan kebijakan, diantaranya Peraturan Pemerintah Pengganti Undang-Undang No. 1 Tahun 2020 tentang Kebijakan Keuangan Negara dan Stabilitas Sistem Keuangan untuk Penanganan Pandemi Corona Virus Disease 2019 (Covid 19) dan/atau dalam Rangka Menghadapi ancaman yang Membahayakan Perekonomian Nasional dan/atau Stabilitas Sistem Keuangan, Peraturan Pemerintah No. 21 Tahun 2020 tentang Pembatasan Sosial Berskala Besar dalam Rangka 
Percepatan Pe-nanganan Corona Virus Disease 2019 (Covid 2019), Keputusan Presiden No. 11 Tahun 2020 tentang Penetapan Kedaruratan Kesehatan Masyarakat Corona Virus Disease 2019 (Covid 2019). Keppres Nomor 12Tahun 2020 ttg Penetapan Covid 19 sebagai Bencana Nasional. Permenkes 9 Tahun 2020 tentang Pedoman Pembatasan Sosial Berskala Besar dalam Rangka Percepatan Penanganan Corona Virus Disease 2019.

Sejumlah peraturan perundang- undangan diatas penting untuk dikeluarkan pemerintah dalam penanggulangan Corona Virus Disease 2019 (Covid 2019). Hal ini mengingat beberapa waktu lalu sempat terjadi miss koordinasi antara pemerintah pusat dan pemerintah daerah dalam penentuan kebijakan dan tanggungjawab terhadapmasyarakat di daerah (Muhawarman et al., 2017). Di satu sisi langkah beberapa daerah dalam mengambil inisiasi kebijakan penanggulangan penyebaran Corona Virus Disease 2019 (Covid 2019) dengan membuat kebijakan "karantina wilayah" atau "local lockdown" secara mandiri sebelum payung hukum dan kebijakan pemerintah pusat diambil dirasa tepat, namun disisi lain juga perlu kebijakan yang tegas dan jelas dalam penanggulangan Covid-19 di Indonesia (Suherman, 2020).

Kondisi darurat akibat Covid-19 da lam kerangka negara kesatuan pun tidak hanya menjadi tanggung jawab pemerintah pusat saja, namun juga perlu peran dan tanggungjawab pemerintah daerah (Ariyanto, 2020). Hal inilah penting bagi pemerintah daerah untuk melakukan inovasi kebijakan penanganan pandemi Covid-19 tanpa mengesampingkan kebijakan yang telah di keluarkan oleh pemerintah pusat. Lebih lanjut dalam perjalanannya hampir satu tahun ini, pemerintah pusat dan pemerintah daerah telah menginisiasi diberlakukanya adaptasi tatanan kebiasaan baru atau "new normal" di masyarakat (Mardiana et al., 2020). Hal ini mengingat Indonesia tidak dapat berlama-lama dalam situasi Covid-19 dengan semakn menurunya ekonomi maupun aspek sosial masyarakat akibat pandemi Covid-19 ini berlangsung. Lebih dari itu, perlu sebuah kebijakan strat- egis yang dibangun pemerintah pusat maupun daerah dalam menanggapi tatanan new normal dalam masyarakat, dengan tetap megedepankan protokol kesehatan dan pencegahan penyebaran Covid-19 (Ilham \& Renyaan, 2021). Untuk itu menjadi menarik untuk di teliti terkait apa urgensi inovasi kebijakan pemerintah daerah dalam penanganan pandemi Covid-19 dan bagaimanakah bentuk inovasi kebijakan yang dilakukan pemerintah daerah dalam penanganan pandemi Covid-19. 


\section{METODE PENELITIAN}

Penelitian ini merupakan penelitian yuridis normatif, dengan mengkaji peraturan perundang-undangan serta teori yang berkaitan dengan dengan hukum da rurat negara, bentuk negara kesatuan serta pemerintahan daerah di Indonesia. Selanjutnya data yang diperoleh dianalisis secara deskriptif kualitatif (Ishaq, 2017).

\section{HASIL DAN PEMBAHASAN}

\subsection{Urgensi Inovasi Pemerintah Daerahdalam penanganan Covid-19}

Gagasan tentang bentuk negara kesatuan sendiri jauh sebelum kemerdekaan Indonesia. Seperti yang di kemukakan oleh Yamin bahwa "dasar unitarisme sejak Kongres Indonesia Muda (Sumpah Pemuda) 28 Oktober 1928 membuang dasar federalism dan kebusukan rasa kepulauan tau kedaerahan (insularisme provincialism) dan menanam kesatuan Indonesia atas dasar persatuan bangsa, daerah tanah air dan Bahasa di bawa lindungan satu bendera Merah-Putih" (Yamin, 2006).

Negara kesatuan menurut Cohen dan Peterson dapat dipahami sebagai suatu negara dimana pemerintah pusat menjalankan kedaulatan tertinggi dalam negara tersebut. Agar pemerintah pusat dapat menjalankan tugasnya dengan efektif maka aktivitasnya diawasi dan dibatasi langsung oleh undangundang. Seluruh unit pemerintahan yang dibentuk dibawah pemerintahan pemerintah pusat harus tunduk kepada pemerintah Pusat secara organisasional berdasarkan peraturan perundang-undangan yang berlaku. Fred Isjwara mengemukakan bahwa negara kesatuan adalah bentuk kenegaraan yang paling kokoh dibandingkan dengan negara federal atau konfederasi, karena di negara kesatuan terdapat persatuan (union) serta kesatuan (unity) (Wasistiono, 2004). Negara kesatuan memiliki dua bentuk, pertaama adalah negara kesatuan bersistem sentralisasi dan negara kesatuan bersistem desentralisasi. Dalam negara kesatuan bersistem sentralisasi seluruh urusan dalam negara langsung diatur oleh pemerintah pusat, semestara daerah akan menjalankan instruksi dari pemerintah pusat tersebut (Simandjuntak, 2016). Sedangkan dalam negara kesatuan bersistem desentralisasi, daerahdaerah diberikan kewenangan untuk mengatur rumah tangganya sendiri.

Menurut Ni'matul Huda, dalam desentralisasi memang tidak mempunyai suatu definisi yang tunggal. Apapun definisi desentralisasi yang dipilih, harus terjadi harmonisasi yang baik antara desentralisasi politik, administrasi, 
dan fiskal. Desentralisasi politik pada intinya memberikan kewenangankepada pemerintah daerah untuk menjalankan suatu kebijakan (Thamrin, 2019). Desentralisasi administrasi atau desentralisasimanajerial memberikan petunjuk bagaimana implementasi dari pengalihan kewenangan fungsi tersebut. Desentralisasi fiskal menyediakan pembiayaan untuk pengalihan kewenangan tersebut (Kharisma, 2013).

Bentuk negara kesatuan Republik Indonesia merupakan amanat Undang-Undang Dasar 1945. Pasal 1 ayat 1 dengan tegas menyatakan bahwa "Negara Indonesia ialah negara kesatuan, yang berbentuk Republik". Prinsip yang terkandung pada negara kesatuan ialah, bahwa yang memegang tampuk kekuasaan tertinggi atas segenap urusan negara adalah Pemerintah Pusat (central government) tanpa adanya gangguan oleh delegasi atau pelimpahan kekuasaan kepada pemerintah daerah (local government) (Barama, 2016).

M Solly Lubis mengatakanbahwa dalam negara kesatuan terdapat asas bahwa segenap urusan-urusan Negara ini tidak dibagi antara Pemerintah Pusat (central government) sedemikian rupa, sehingga urusan-urusan Negara dalam Negara Kesatuan itu tetap merupakan suatu kebulatan (eenheid) dan bahwa pemegang kekuasaan tertinggi di negara itu adalah Pemerintah Pusat (Lubis, 2007). Bentuk negara kesatuan sebagai pilihan dianggap paling tepat untuk Indonesia. Dalam Pasal 18 UUD NRI ditegaskan bahwa Negara kesatuan republik Indonesia dibagi atas daerah-daerah provinsi dan daerah provinsi itudibagi atas kabupaten dan kota, yang tiap-tiap provinsi, kabupaten, dan kota itu mempunyai pemerintahan daerah, yang diatur dengan UndangUndang. Selanjutnya hubungan antara pemerintah pusat dengan daerah ditegaskan pula dalam Pasal 18A UUD NRI Tahun 1945, bahwa hubungan wewenang antara pemerintah pusat dan pemerintah daerah propinsi, kabupaten, kota, atau antara propinsi dan kabupaten dan kota, diatur dengan undang- undang dengan memperhatikan kekhususan dan keragaman daerah. Hubungan keuangan, pelayanan umum, pemanfaatan sumber daya alam dan sumber daya lainnya antara pemerintahan pusat dan pemerintahan daerah diatur dan dilaksanakan secara adil dan selaras berdasarkan undang-undang (Nasution, 2011).

Bentuk negara kesatuan yang terdesentralisasi yang terdiri atas pemerintahan daerah provinsi dan kabupaten kota ini lah yang penyelenggaraannya dilaksanakan melalui asas otonomi daerah beserta hubungan antara pemerintah pusat dan pemerintah daerah, yang diatur lebih lanjut dengan 
Undang-Undang Nomor 23 Tahun 2014 tentang Pemerintahan Daerah (UU Pemda). Dalam konteks negara kesatuan, tanggung jawab pelaksanaan pemerintahan tetap berada di tangan pemerintah pusat, namun dikarenakan salah satu asas yang dipergunakan dalam sistem pemerintahan di Indonesia adalah asas negara kesatuan yang didesentralisasikan maka ada tugas-tugas yang diurus sendiri oleh daerah sehingga lahirlah hubungan kewenangan dan yang mengatur mekanisme keseimbangan tuntutan kesatuan dengan tuntutan otonomi yang pengawasan antara pusat dan daerah (Nur Wijayanti, 2017).

Dilihat dari status hierarkhi, pemerintah daerah merupakan wakil pemerintah pusat di daerah dalam pelaksanaan urusan-urusan tertentu, namun disisi lain pemerintah daerah membawa status sebagai wakil rakyat di daerah yang dengan kewenangan otonominya dapat mengatur dan mengurus rumah tangganya sendiri untuk kepentingan dan kesejahteraan rakyat di daerah (Makhfudz, 2019). Oleh karenanya dapat dikatakan desentralisasi yang dilaksanakan di daerah bertujuan politik dan ekonomi. Tujuan politik dapat dilihat dengan tujuan memperkuat kedudukan pemerintah daerah, aparat pemerintah daerah maupun masyarakat di daerah, dan mempertahankan integrasi nasional dalam bingkai negara kesatuan. Sedangkan tujuan ekonomi, dapat dilihat dari upaya yang dilakukan oleh pemerintah daerah guna menyediakan pelayanan publik kepada masyarakat (Hamid, 2011).

Pola hierarkhi yang diperlukan adalah memberi keleluasaan daerah untuk menerapkan kebijakan dan program untuk memajukan daerah. Suatu kebijakan yang memberikan kepastian dan keterukuran serta jaminan pada masyarakat di daerah. Pemerintah pusat sebagai pemegang amanat kepentingan nasional memiliki tanggung jawab akhir dan yang juga memiliki tugas dan fungsinya sendiri. Oleh karenanya dalam realitasnya terdapat problematika terdapat hubungan diantara keduanya, yakni pertama adanya hubungan koordinasi, bimbingan dan pengawasan (korbinwas) antar jenjang pemerintahan yang sejauh ini kesan yang tampakseolah daerah jalan sendirisendiri dalam membuat kebijakan bagi daerahnya. Kedua, pemerintah pusat sebagai pembuat NSPK menjadi kendala bagi daerah-daerah dalam melaksanakan otonomi, karena terkunci dengan bagaimana daerah membangun daerah sekaligus ekonomi di daerah. Ketiga control kuat dari pemerintah pusat melalui NSPK akan dapat menciptakan sinkronisasi, sinergi, dan koordinasi antar jenjang pemerintahan secara realitas terjadi adalah kebalikannya (Zuhro, 2020). 
Fungsi kordinasi bimbingan dan pengawasan yang belum efektif ini menjadikan daerah seolah-olah jalan sendiri untuk mengatasi persoalanpersoalan yang muncul di daerah. Sehingga menimbulkan kesan antara pemerintah pusat dan daerah belum satu perpektif dalam menjalankan otonomi.

Melihat pada hal-hal yang telah disampaikan diatas, problem hubungan pusat dan daerah juga terjadi dalam realitas penanganan Covid-19 dalam kerangka negara kesatuan di Indonesia. Pemerintah pusat telah mengambil Langkah dengan mengeluarkan beberapa kebijakan strategis untuk mitigasi Covid-19 diantaranya Peraturan Pemerintah Pengganti Undang-Undang No. 1 Tahun 2020 tentang Kebijakan Keuangan Negara dan Stabilitas Sistem Keuangan untuk Penanganan Pandemi Corona Virus Disease 2019 (Covid 19) dan/atau dalam Rangka Menghadapi ancaman yang Membahayakan Perekonomian Nasional dan/atau Stabilitas Sistem Keuangan, Peraturan Kendali sebagai pembuat norma, standar, prosedur dan kriteria (NSPK) yang memiliki tugas dan fungsi sendiri. Sedangkan pemerintah daerah sebagai bagian negara kesatuan juga memegang amanat kepentingan nasional sebagai sub sistem pemerintah nasional Pemerintah No. 21 Tahun 2020 tentang Pembatasan Sosial Berskala Besar dalam Rangka Percepatan Penanganan Corona Virus Disease 2019 (Covid 2019), Keputusan Presiden No. 11 Tahun 2020 tentang Penetapan Kedaruratan Kesehatan Masyarakat Corona Virus Disease 2019 (Covid 2019). Keppres Nomor 12 Tahun 2020 tentang Penetapan Covid 19 sebagai Bencana Nasional. Permenkes 9 Tahun 2020 tentang Pedoman Pembatasan Sosial Berskala Besar dalam Rangka Percepatan Penanganan Corona Virus Disease 2019 hingga Instruksi Presiden Nomor 6 Tahun 2020 tentang Peningkatan Disiplin dan Penegakan Hukum Protokol Kesehatan Dalam Pencegahan dan Pengendalian Corona Virus Disease 2019. Namun dalam realitasnya peraturan perundang-undangan maupun kebijakan yang di keluarkan oleh pemerintah pusat belum cukup mampu mengatasi pandemi Covid-19 secara efektif di Indonesia. Tanggungjawab penanganan Covid-19 memang menjadi tanggung jawab pemerintah pusat dengan mengambil berbagai kebijakan strategis di Indonesia, namun banyak pihak menyatakan bahwa kebijakan ini tidak cukup signifikan mengatasi Pandemi Covid-19 hingga hampir satu tahun ini. Kebijakan penanganan Covid-19 yang dilakukan pemerintah pusat melalui 3T (testing, tracing, treatment) dan 3M tanggung jawab terhadap kesehatan dan keselamatan masyarakat. Oleh karenanya 
kebijakan pemerintah daerah acap kali lebih responsif di bandingkan oleh pemerintah pusat.

Pemerintah daerah yang lebih dahulu mengambil langkah antisipasidan penanganan Covid-19 tentu saja tak bermaksud mendahului atau 'membangkang' pada pemerintah pusat. Secara umum, pastinya mempunyai maksud baik, yaitu untuk melindungi masyarakat yang telah memberikannya 'mandat' secara konstitusional melalui pemilihan umum sebagaimana Pasal 18 Ayat 4 UUD 1945. Secara sadar, tentu pemerintah daerah merasa mempunyai tanggung jawab atas kondisi wabah yang terjadi di masyarakat, yang bahkan menyebabkan korban jiwa. Karena kesehatan merupakan salah satukewajiban pemerintah daerah kepada masyarakatnya, sebagaimana amanat UndangUndang Nomor 23 Tahun 2014 tentang Pemerintah Daerah. Sehingga jika pemerintah daerah 'berdiam diri', tentu akan mendapatkan 'serangan' aksi dari masyarakat untuk menagih tindakan konkrit atas problem yang terjadi ini, akan menjadi 'beban' pemerintah daerah ketika tidak mengambil langkah dengan cepat (Mandasari, 2021).

Tindakan responsif dan inovatif pemerintah daerah dalam mengambil kebijakan-kebijakan mengatasi pandemi Covid-19 yang kadang dirasa masih tidak efektif menekan penyebaran Covid-19, tata regulasi yang dibuat oleh pemerintah pusat acap kali terlambat dan belum mampu mengatasi masalah pandemi yang dibutuhkan masyarakat. Disisi lain di level daerah pemerintah daerah sebagai wakil pemerintah pusat dan wakil rakyat berimbulkan berbagai konflik dengan pemerintah daerah tentu saja tidak dapat di salahkan secara keseluruhan. Hal ini mengingat, meskipun pemerintah daerah secara hierarkhi adalah wakil pemerintah pusat, namun secara politik pemerintah daerah merupakan wakil rakyat di daerah. Selain itu, secara filosofi tujuan bernegara "melindungi segenap bangsa Indonesia dan seluruh tumpah darah Indonesia, memajukan kesejahteraan umum, mencerdaskan kehidupan bangsa, dan melaksanakan ketertiban dunia" tidak hanya menjadi tanggung jawab pemerintah pusat, namun juga perlu tanggung jawab pemerintah daerah dalam mewujudkannya, baik dalam keadaan negara normal maupun keadaan darurat negara seperti pandemi Covid19 saat ini.

Selain itu dalam UU No. 23 tahun 2014 tentang Pemerintahan Daerah (UU Pemda) yang memberikan peluang pemerintah daerah untuk melakukan inovasi, sebagaimana diatur dalam Pasal 386 yang menyatakan bahwa "dalam rangka peningkatan kinerja penyelenggaraan Pemerintahan Daerah, 
Pemerintah Daerah dapat melakukan inovasi". Inovasi seperti yang termuat dalam Pasal 386 UU Pemda ini juga dapat dimaksnai inovasi yang berkaitan dengan penanganan Covid-19 di masing-masing daerah.

Terakhir, urgensi inovasi yang dilakukan oleh pemerintah daerah ini penting dilakukan dengan merujuk pada adagium Salus populi suprema lex yang berarti keselamatan rakyat harus menjadi tujuan yang paling utama. Oleh karenanya, pemerintah daerah menjadi relevan untuk melakukan inivasi kebijakan penangangan Covid 19 karena memiliki tanggungjawab besar untuk mewujudkan kesehatan dan keselamatan rakyat di masa pandemi ini. Tentu saja, dalam implementasinya tidak hanya berpijak pada asas tersebut, namun juga harus perpedoman pada konstitusi dan aturan hukum yang berlaku.

\subsection{Bentuk Inovasi Kebijakan Pemerintah Daerah}

Setidaknya ada tiga hal yang dapat dilakukan oleh pemerintah daerah dalam inovasi penanganan covid-19. Pertama berkaitan dengan pemulihan sektor birokrasi dan pelayanan masyarakat. Dalam hal ini Pemerintah dapat berpedoman pada:

1. SE Menteri PANRB 58/2020 Dalam SE ini memuat sistem kerja bagi Pegawai Aparatur Sipil Negara (ASN) dalam penyelenggaraan pemerintahan di lingkungan Kementrian/Lembaga/Daerah untuk beradaptasi dengan tatanan normalbaru produktif dan aman Covid-19. Selain itu juga terdapat penyesuaian jam kerja bagi ASN baik Work from Home (WFH), Work from Office (WFO), maupun perjalanan dinas; management SDM dg memperhatikan kinerja dan disiplin kerja; Infrastruktur normal baru: prasarana, IT dan protokol kesehatan Untuk menjamin kelancaran penyelenggaraan pelayanan public Kementrian/Lembaga/Daerah agar:

a. Melakukan penyederhanaan proses bisnis dan standar operasional prosedur pelayanan dengan memanfaatkan teknologi informasi dan komunikasi;

b. Menggunakan media informasi untuk penyamapaian standar pelayanan baru melakui media publikasi;

c. Membuka media komunikasi online sebagai wadah konsultasi maupun pengaduan; 
d. Memastikan bahwa output dari produk pelayanan yang dilakukan secara online maupun offline tetap sesuai dengan standar yang telah di tetapkan;

e. Memperhatikan jarak aman (physical distancing), kesehatan, dan keselamatan pegawai yang melakukan pelayanan langsun secara offline dengan protocol kesehatan yang ditetapkan oleh Menteri kesehatan.

2. SE Menteri PANRB No 64/2020 Dalam surat edaran tersebut memuat perjalanan dinas yang kembali diperbolehkan, namun dengan memperhatikan zona penyebaran Covid-19 dan mengutamakan protocol kesehatan.

3. SE Menteri PANRB No 67/2020 Surat edaran ini merupakan perubahan terhadap SE Menteri PANRB No.58/2020. Dimana dilakukan penyesuaian proporsi Work from Home (WFH) dan Work from Office (WFO)

berdasarkan zona kabupaten/kota.

Selain itu juga dilakukan pembedaan terhadap zona terdampak, rendah, sedang, tinggi terkait dengan pelayanan masyarakat, sebagai contoh pemerintah Daerah Istimewa Yogyakarta telah mengeluarkan Peraturan Gubernur No. 48 Tahun 2020 tentang Pedoman Penyusunan Panduan PelaksanaanKegiatan Pelayanan Publik dan Perekonomian Masyarakat di DIY dalam Pencegahan dan Pengendalian Covid-19. Peraturan Gubenur ini menjadi salah satu kebijakan pemerintah daerah guna mengatur kegiatan pelayanan publik dan perekonomian masyarakat di Yogyakarta tetap berjalan namun juga tetap mengedepankanpencegahan dan pengendalian Covid-19.

Kedua, berkaitan dengan inovasi di sektor kesehatan dan/atau ketertiban masyarakat. Lahirnya Inpres 6 Tahun 2020 Peningkatan Disiplin Dan Penegakan Hukum Protokol Kesehatan Dalam Pencegahan Dan Pengendalian Covid 19 memberikan peluang kepada pemerintah dalam hal ini Gubernur, Bupati, dan Walikota untuk membentuk Peraturan Gubernur, Peraturan Bupati, maupun Peraturan Walikota terkait Penegakan Hukum Protokol Kesehatan berdasarkan kearifan lokal di masing-masing daerah. Di dalam peraturan kepala daerah tersebut, tidak hanya berisi edukasi secara massif terkait dengan protokol Covid-19 maupun PHBS dalam masyarakat, namun juga dapat mengatur sanksi bagi individu, kelompok, maupun pelaku usaha yang melanggar ketentuan dalam peraturan lepala daerah tersebut, yang dalam pelaksanaanya dapat berkoordinasidengan lembaga terkait seperti TNI maupun Polri. 
Di Daerah Istimewa Yogyakarya sendiri telah ada beberapa peraturan kepala daerah terkait, berkenaan dengan ketertiban masyarakat dalam upaya penanggulangan Covid-19, diantaranya di level provinsi Gubernur DIY telah mengeluarkan Peraturan Gubernur (Pergub) Nomor 77 Tahun 2020 tentang Penerapan Disiplin dan Penegakan Hukum Protokol Kesehatan Sebagai Upaya Pencegahan dan Pengendalian Covid-19. Aturan ini meliputi pelaksanaan, monitoring dan evaluasi, sanksi, sosialisasi dan partisipasi, serta pendanaan. Pada ruang lingkup pelaksanaan, subjek pengaturan mencakup perorangan, pelaku usaha, dan pengelola, penyelenggara atau penanggung jawab tempat dan fasilitas umum. Di Kabupaten Sleman, Bupati mengeluarkan Peraturan Bupati Sleman No. 37.1 Tahun 2020 tentang Penerapan Disipin dan Penegakan Hukum Protokol Kesehatan sebagai Upaya Pencegahan dan Pengendalian Covid-19 dan juga mengeluarkan Intruksi Bupati Sleman No. 443/0021 tentang Peningkatan Kewaspadaan dan penaganan terhadap Resiko Penularan Infeksi Covid-19. Kemudian Peraturan Bupati Bantul No. 79 Tahun 2020 tentang Adaptasi Kebiasaan Baru Protokol Kesehatan Pencegahan Covid-19, dan sejumlah peraturan kepala daerah di wilayah DIY lainya.

Dengan adanya peraturan kepala daerah ini, secara payung hukum telah memadai dalam pening- katan ketertiban masyarakat dalam pencegahan Covid-19, namun perlu optimalisasi pelaksanaan dari peraturan kepala daerah tersebut oleh semua pihak baik pemerintah daerah perangkat daerah, dan masyarakat, sehingga dapat menekan angka penyebaran Covid-19 khususnya di DIY.

Disisi lain dari segi formalitas, pembentukan peraturan kepala daerah ini memunculkan pertanyaan kesesuaian isi pengaturan yang berlaku secara umum yang diatur dengan peraturan kepala daerah ini apakah tepatatau tidak. Saat ini Perkada atau Peraturan Kepala Daerah (Peraturan Gubernur/Peraturan Bupati/Peraturan Wali Kota) menjadi sesuatu yang penting dalam penyelenggaraan pemerintahandaerah. Perkada sudah menjadi salahsatu jenis peraturan perundang-undangan. Perkada menjadi salah satu produk hukum daerah berbentuk pengaturan selain Perda dan Peraturan DPRD. Perkada menjadi pilihan penyusun, perumus, dan pembentuk peraturan perundangundangan di lingkungan Kementerian/Lembaga untuk menjadi kuasa peraturan perundang-undangan dan untuk melaksanakan Perda (Peraturan Daerah), serta Perkada sebagai pelaksana perintah peraturan perundangundangan yang lebih tinggi dan dibentuk berdasarkan kewenangan. 
Pengaturan atas Perkada sebagai kuasa peraturan perundang-undangan dan untuk melaksanakan Perda merupakan bagian pengaturan yang ditetapkan dalam Pasal 246 ayat (1) Undang-undang Nomor 23 Tahun 2014 tentang Pemerintahan Daerah, "Untuk melaksanakan Perda atau atas kuasa peraturan perundang-undangan, kepala daerah menetapkan Perkada". Pengaturan Perkada sebagai pelaksana perintah peraturan perundang- undangan yang lebih tinggi dan diben- tuk berdasarkan kewenangan ditetap-kan dalam Pasal 8 ayat (2) Undang- undang Nomor 12 Tahun 2011 tentang Pembentukan Peraturan Perundang-undangan, "Peraturan Perundang-undangan sebagaimana dimaksud pada ayat (1) diakui keberadaannya dan mempunyai kekuatan hukum mengikat sepanjang diperintahkan oleh Peraturan Perundang-undangan yang lebih tinggi atau dibentuk berdasarkan kewenangan". Namun disisi lain, dalam keadaan tertentu pejabat publik dalam hal ini adalah kepala daerah memiliki kewenangan untuk membetuk peraturan kebijakan dalam bentuk peraturan kepala daerah dengan syarat adanya kewenangan diskresi yang dimiliki pejabat publik untuk mengambil kebijakan secara cepat untuk mengatasi kondisi darurat tersebut.

Melihat pertimbangan tehadap jangkauan materi muatan peraturan kepala daerah dan pelaksana perintah dari peraturan perundang-undangan diatasnya, dan di dukung dengan kenyataan bahwa Covid-19 ini merupakan jenis penyakit dengan tingkat penularan yang tinggi (seperti HIV dan Hepatitis) kedepan perlu diatur lebih lanjut dalam Peraturan Daerah di level Provinsi maupun Kabupaten/Kota terkait pencegahan penyakit menular, yang memungkinkan tidak hanya Covid-19 maupun jenis penyakit lainyang telah di temukan, namun juga memungkinkan untuk jenis penyakit dengan resiko penyebaran tinggi. Pengaturan lebih lanjut dalam level peraturan daerah ini juga agar lebih bersifat menyeluruh tidak hanya berkaitan dengan sejumlah himbauan dan larangan dalam penanggulangan Covid-19 maupun penyakit lainya, namun juga agar lebih komprehensifmengatur mengenai upaya-upaya pencehagan dan pengendalian, pemantauan, pemulihan, maupun pengawasan terhadap jenis penyakit menular (Widayatun \& Fatoni, 2013).

Ketiga, inovasi dibidang ekonomi yang dilakukan oleh pemerintah daerah, diantaranya yakni memberikan fasiltas perpajakan seperti adanya penundaan pembayaran pajakterdampak seperti hotel, restoran, parkir dalam kurun waktu tertentu, memperpanjang jatuh tempo PBB dalam kurun waktu tertentu, penghapusan denda tarif retribusi tertentu, melakukan stimulus dan 
pemberdayaan UMKM, dan peningkatan serapan anggaran keuangan daerah. Dengan setidaknya tiga inovasi yang telah dibahas di atas, pemerintah daerah diharapkan akan lebih siap dalam pelaksanaan tatanan kebiasaan baru (new normal) dimasa yang akan datang.

\section{KESIMPULAN}

Inovasi kebijakan pemerintah dae rah menjadi penting dilakukan dalam penanganan pandemi Covid-19 karena Peran Gubernur dalam berapa alasan, yakni pertama dalam konteks negara kesatuan terdapat hubungan antara pemerintah pusat dan daerah baik hubungan kewenangan, keuangan, maupun hubungan pengawasan, kedua adanya problematika hubungan antara pemerintah pusat dan pemerintah daerah secara umum maupun dalam penanganan Covid-19 di Indonesia mengakibatkan ketidak efektifan kebijakan penanganan Covid-19 yang dilakukan oleh pemerintah pusat dan daerah. Ketiga, sejumlah peraturan dan kebijakan pemerintah pusat belum cukup efektif mengatasi pandemi Covid-19. Kempat, pemerintah daerah sebagai bagian pemerintah pusat dan wakil rakyat di daerah memiliki tanggung jawab langsung kepada masyarakat di terhadap Kesehatan dan keselamatan rakyat di daerah. Kelima, bahwa inovasi penanganan Covid-19 yang dilakukan pemerintah daerah sebagai bagian dari kepentingan nasional guna melaksanakan tujuan bernegara yang berpegang pada asas solus populi suprema lex.

Bentuk inovasi kebijakan yang dilakukan pemerintah daerah dalam penanganan pandemi Covid-19 diantaranya pertama, mengefektifkan berkaitan dengan pemulihan sektor birokrasi dan pelayanan masyarakat. Kedua, berkaitan dengan inovasi di sektor kesehatan dan/atau ketertiban masyarakat. Ketiga, inovasi dibidang ekonomi yang dilakukan oleh pemerintah daerah, diantaranya yakni memberikan fasiltas perpajakan.

\section{DAFTAR PUSTAKA}

Adhari, A. (2019). Ambiguitas Pengaturan Keadaan Bahaya dalam Sistem Ketatanegaraan Indonesia. Dialogia Iuridica, 11(1), 43-61.

Ariyanto, B. (2020). Pengelolaan Hubungan Antar Pusat dan Daerah. Suloh Jurnal Program Studi Magister Hukum, Edisi Khus(Oktober), 37-57.

Barama, M. (2016). Pelaksanaan Pemerintahan Daerah dan Penerapan Sanksi Adiminstrasi dalam Peraturan Daerah. Jurnal Hukum Unsrat, 22(5), 28-39. 
Hamid, A. (2011). Otonomi Daerah dan Pelayanan Publik. Jurnal Academica, 03(01), 535-546.

Ilham, \& Renyaan, D. (2021). Edukasi Membudayakan Protokol Kesehatan Pada Masa Pandemi Covid-19 Di Kampung Yobeh Distrik Sentani Kabupaten Jayapura. JMM (Jurnal Masyarakat Mandiri), 5(1), 12-23. http://journal.ummat.ac.id/index.php/jmm/article/view/3186/pdf

Ishaq. (2017). Metode Penelitian Hukum Dan Penulisan Skripsi, Tesis, Serta Disertasi. In ALFABETA, cv.

Iswahyudi, F., Darwin, M., Hadna, A. H., \& Kutanegara, P. M. (2020). Kontekstualisasi Adopsi Kebijakan: Studi Kasus Kebijakan Pengendalian Covid-19 di Korea Selatan. Jurnal Borneo Administrator, 16(2), 117-136. https://doi.org/10.24258/jba.v16i2.682

Kharisma, B. (2013). Desentralisasi Fiskal Dan Pertumbuhan Ekonomi : Sebelum Dan Sesudah Era Desentralisasi Fiskal Di Indonesia. Jurnal Ekonomi Dan Studi Pembangunan, 14(2), 101-119.

Lubis, M. S. (2007). Pergeseran Garis Politik dan Perundang-Undangan Mengenai Pemerintah Daerah, . Alumni.

Makhfudz, M. (2019). Kontroversi Pelaksanaan Otonomi Daerah. ADIL: Jurnal Hukum, 3(2), 380-406. https://doi.org/10.33476/ajl.v3i2.816

Mandasari, Z. (2021). Tarik Menarik Penanganan Covid-19. Ombudsman.Go.Id. https://ombudsman.go.id/artikel/r/artikel\%0A--tarik-menarik-

penanganan-covid-19\%0A

Mardiana, U., Novitriani, K., Virgianty, D. P., \& Irmayanti, E. (2020). Upaya Peningkatan Kebiasaan Mencuci Tangan Sebagai Bagian Dari Gerakan 3 M Melalui Donasi Sabun Cuci Tangan Hasil Produksi Tim Kelompok Pengabdian. Jurnal Pengabdian Masyarakat, 1(2), 57-66.

Muhawarman, A., Ayuningtyas, D., \& Misnaniarti, M. (2017). Formulasi Kebijakan Komunikasi Untuk Pelaksanaan Program Pembangunan Kesehatan. Media Kesehatan Masyarakat Indonesia, 13(2), 97. https://doi.org/10.30597/mkmi.v13i2.1980

Nasution, F. A. (2011). Kebijakan Perimbangan Keuangan Antara Pemerintah Pusat Dan Daerah Pasca Reformasi. Jurnal Hukum \& Pembangunan, 18(3), 381-404. https://doi.org/10.21143/jhp.vol41.no4.257

Nuh, M. S. N. S. (2011). Hakekat Keadaan Darurat Negara (State of Emergency) Sebagai Dasar Pembentukan Peraturan Pemerintah Pengganti UndangUndang. Jurnal Hukum Ius Quia Iustum, 18(2), 229-246. https://doi.org/10.20885/iustum.vol18.iss2.art5

Nur Wijayanti, S. (2017). Hubungan Antara Pusat dan Daerah Dalam Negara Kesatuan Republik Indonesia Berdasarkan Undang-Undang Nomor 23 
Tahun 2014. Jurnal Media Hukum, 23(2), 186-199. https://doi.org/10.18196/jmh.2016.0079.186-199

Sagama, S. (2016). Analisis Konsep Keadilan, Kepastian Hukum dan Kemanfaatan dalam Pengelolaan Lingkungan. Mazahib, 15(1), 20-41. https://doi.org/10.21093/mj.v15i1.590

Samudro, E. G., \& Madjid, M. A. (2020). Pemerintah Indonesia Menghadapi Bencana Nasional Covid -19 Yang Mengancam Ketahanan Nasional. Jurnal Ketahanan Nasional, 26(2), 132. https://doi.org/10.22146/jkn.56318

Simandjuntak, R. (2016). Sistem Desentralisasi Dalam Negara Kesatuan Republik Indonesia Perspektif Yuridis Konstitusional. Journal de Jure, 7(1), 57. https://doi.org/10.18860/j-fsh.v7i1.3512

Suherman, D. (2020). Peran Aktor Kebijakan Pembatasan Sosial Berskala Besar Dalam Mengatasi Penyebaran COVID-19 Di Indonesia. Ministrate: Jurnal Birokrasi Dan Pemerintahan Daerah, 2(2), 51-62. https://doi.org/10.15575/jbpd.v2i2.9383

Thamrin, A. (2019). Politik Hukum Otonomi Daerah Dalam Mewujudkan Tata Kelola Pemerintahan Yang Baik di Bidang Kesehatan. Al-Adalah: Jurnal Hukum Dan Politik Islam, 4(1), 33-51. https://doi.org/10.35673/ajmpi.v4i1.130

Wasistiono, S. (2004). Kajian Hubungan antara Pemerintah Pusat dengan Pemerintah Daerah (Tinjauan dari Sudut Pandang Manajemen Pemerintahan). Jurnal Administrasi Pemerintahan Daerah, 1(2), 9.

Widayatun, \& Fatoni, Z. (2013). Permasalahan Kesehatan dalam Kondisi Bencana:Peran Petugas Kesehatan dan Partisipasi Masyarakat (Health Problems in a Disaster Situation : the Role of Health Personnels and Community Participation). Jurnal Kependudukan Indonesia, 8(1), 37-52.

Yamin, M. (2006). Proklamasi dan Konsitusi Re publik Indonesia. Djambatan. Zuhro, S. (2020). Relasi Pemerintah Pusat dan Daerah Era Covid-19. 